University of Nebraska - Lincoln

DigitalCommons@University of Nebraska - Lincoln

November 1994

\title{
ANISOTROPY AND MAGNETO-OPTICAL PROPERTIES OF SPUTTERED CO/Ni MULTILAYER THIN FILMS
}

\author{
Y.B. Zhang \\ University of Nebraska - Lincoln \\ John A. Woollam \\ University of Nebraska-Lincoln, jwoollam1@unl.edu \\ Z.S. Shan \\ University of Nebraska - Lincoln \\ J.X. Shen \\ University of Nebraska - Lincoln \\ David J. Sellmyer \\ University of Nebraska-Lincoln, dsellmyer@unl.edu
}

Follow this and additional works at: https://digitalcommons.unl.edu/physicssellmyer

Part of the Physics Commons

Zhang, Y.B.; Woollam, John A.; Shan, Z.S.; Shen, J.X.; and Sellmyer, David J., "ANISOTROPY AND MAGNETO-OPTICAL PROPERTIES OF SPUTTERED Co/Ni MULTILAYER THIN FILMS" (1994). David Sellmyer Publications. 103.

https://digitalcommons.unl.edu/physicssellmyer/103

This Article is brought to you for free and open access by the Research Papers in Physics and Astronomy at DigitalCommons@University of Nebraska - Lincoln. It has been accepted for inclusion in David Sellmyer Publications by an authorized administrator of DigitalCommons@University of Nebraska - Lincoln. 


\title{
ANISOTROPY AND MAGNETO-OPTICAL PROPERTIES OF SPUTTERED Co/Ni MULTILAYER THIN FILMS
}

\author{
Y. B. Zhang and J. A. Woollam \\ Center for Microelectronic and Optical Materials Research, and Department of Electrical Engineering, \\ University of Nebraska, Lincoln, NE 68588-0511
}

Z. S. Shan, J. X. Shen and D. J. Sellmyer

Center for Materials Research and Analysis, and Department of Physics, University of Nebraska, Lincoln, NE 68588-0111

\begin{abstract}
Several series of sputtered $\mathrm{Co} / \mathrm{Ni}$ multilayer thin films have been investigated. The volume and interface contributions to the magnetic anisotropy were determined from magnetization measurements, and the interface anisotropy, $K_{1}=0.23 \pm 0.03 \mathrm{erg} / \mathrm{cm}^{2}$, was found to support perpendicular magnetic anisotropy. The anisotropy constant, $K$, increased with the Au buffer layer thickness, indicating the buffer layer was crucial to the perpendicular magnetic anisotropy. The polar Kerr rotation and coercivity as a function of temperature, and room temperature magneto-optical figure of merit are presented in this paper.
\end{abstract}

\section{INTRODUCTION}

Multilayered structures have attracted much attention in many fields of materials science owing to the possibility of creating new structures and physical properties. One interesting phenomenon observed in magnetic multilayered thin films is the preference for magnetization perpendicular to the film plane: perpendicular magnetic anisotropy (PMA). This property is displayed by several $\mathrm{Co} / \mathrm{X}$ multilayers, where $\mathrm{X}$ is a noble non-magnetic metal such as $\mathrm{Pd}, \mathrm{Pt}, \mathrm{Au}$, or Ir. [1],[2] Large perpendicular magnetic anisotropy shown in these multilayers makes them potential candidates for $\mathrm{MO}$ recording media.

Recently, Co/Ni multilayer thin films were also predicted to have perpendicular magnetic anisotropy, ${ }^{[3]}$ and this was confirmed in e-beam evaporated ${ }^{[4]}$ and sputtered ${ }^{[5]}$ samples. The perpendicular magnetic anisotropy is due to the positive interface anisotropy[4], and is strongly buffer layer dependent ${ }^{[6]}$. Our previous paper showed perpendicular magnetic anisotropy for $\mathrm{Co} / \mathrm{Ni}$ multilayers on $\mathrm{Au}$ buffer layers, while the same films on Ag buffer layers showed inplane anisotropy. ${ }^{[5]}$ This paper reports the anisotropy of sputtered $\mathrm{Co} / \mathrm{Ni}$ multilayer thin films with $\mathrm{Au}$ buffer layers as a function of $\mathrm{Co}$ and $\mathrm{Ni}$ layer thicknesses. The effect of $\mathrm{Au}$ buffer layers is discussed in terms of the anisotropy constant and $x$-ray measurements. The polar Kerr rotation (as a function of temperature) and the magneto-optic figure of merit are also reported to investigate the possibility of using $\mathrm{Co} / \mathrm{Ni}$ multilayer thin films as MO recording media.

Manuscript received April 4, 1994

The research is supported by National Science Foundation under Grant No. DMR-9222976.

\section{EXPERIMENTS}

Several series of $\mathrm{Co} / \mathrm{Ni}$ multilayer thin films were prepared by magnetron sputtering. The system was evacuated to below $5 \times 10^{-7}$ Torr before sputtering, and Ar gas ( $5 \times 10^{-3}$ Torr for Au target and $15 \times 10^{-3}$ Torr for Co and $\mathrm{Ni}$ targets ) was used in the sputtering process. The source to substrate distances were fixed at about $10 \mathrm{~cm}$. A series of $8 \times(2 \AA \mathrm{Co} / t \AA \mathrm{Ni})$ multilayers was made with $\mathrm{Ni}$ thickness, $t$, ranging from $2 \AA$ to $40 \AA$. A second series of $8 \times(t \AA \mathrm{Co} / 8 \AA \mathrm{Ni})$ multilayers was made with $\mathrm{Co}$ thickness varying from $1.2 \AA$ to $20 \AA$. These two series were deposited on $450 \AA$ thick $\mathrm{Au}$ buffer layers, which were deposited on glass substrates at room temperature. In the third series, $8 \times(2 \AA \mathrm{Co} / 8 \AA \mathrm{Ni})$ multilayers were deposited onto $\mathrm{Au}$ buffer layers of varying thicknesses. ( $50 \AA$ to $650 \AA$ ) The deposition rates for $\mathrm{Co}, \mathrm{Ni}$ and $\mathrm{Au}$ were $0.9 \AA / \mathrm{s}, 1.3 \AA / \mathrm{s}$ and $3.4 \AA / \mathrm{s}$, with corresponding input powers of $30 \mathrm{~W}, 75 \mathrm{~W}$, and $40 \mathrm{~W}$ respectively. Multilayered structures were realized by rotating the substrates above separate guns.

The magnetic anisotropy was determined from the area within the perpendicular (i. e. $\vec{H} \perp$ film plane) and parallel (i. e. $\vec{H} / /$ film plane) magnetization curves ${ }^{[1]}$. An X-ray diffractometer was used to determined the sample and buffer layer textures. Kerr rotation, $\theta_{\mathrm{k}}$, and Kerr ellipticity, $\varepsilon_{\mathrm{k}}$, were measured at normal incidence over the wavelength range from $3000 \AA$ to $8000 \AA$.

\section{RESULTS AND DISCUSSION}

\section{A. Anisotropy}

Magnetic anisotropy can be written as:

$$
\mathrm{KD}=\mathrm{K}_{\mathrm{v}}{ }^{\mathrm{Co}} \mathrm{t}_{\mathrm{Co}}+\mathrm{K}_{\mathrm{v}}{ }^{\mathrm{Ni}} \mathrm{t}_{\mathrm{Ni}}+2 \mathrm{~K}_{\mathrm{i}}
$$

where $\mathrm{K}$ is the anisotropy of the sample, $\mathrm{D}$ is the bilayer thickness, $\quad K_{v}{ }^{C o}$ and $K_{v}{ }^{N i}$ are volume anisotropies corresponding to the $\mathrm{Co}$ and $\mathrm{Ni}$ layers respectively, $\mathrm{K}_{\mathrm{i}}$ is the $\mathrm{Co} / \mathrm{Ni}$ interface anisotropy constant, and $\mathrm{t}_{\mathrm{Co}_{0}}$ and $\mathrm{t}_{\mathrm{Ni}}$ are the $\mathrm{Co}$ and $\mathrm{Ni}$ layer thicknesses. It follows that $\mathrm{KD}$ changes linearly with $t_{\mathrm{C}_{0}}$ when $t_{\mathrm{Ni}}$ is fixed; that is, 


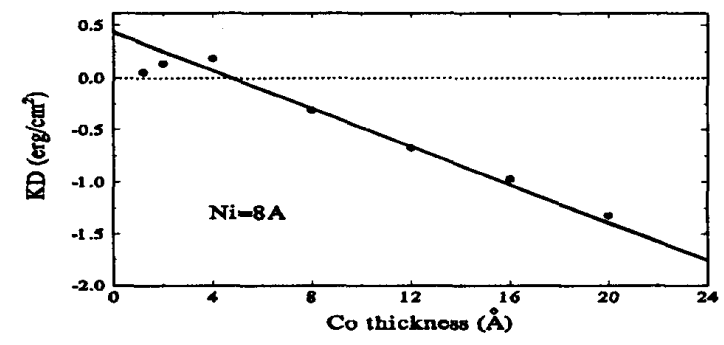

Fig. 1 Anisotropy constant times bilayer period as a function of $\mathrm{Co}$ thickness for $8 \times(t \mathrm{ACo} / 8 \mathrm{ANi})$ multilayers

$$
\mathrm{KD}=\mathrm{K}_{\mathrm{v}}{ }^{\mathrm{Co}} \mathrm{t}_{\mathrm{Co}}+\mathrm{K}\left(\mathrm{t}_{\mathrm{Ni}}\right)
$$

where $K\left(t_{N i}\right)=K_{v}^{N i} t_{N i}+2 K_{i}$.

Fig. 1 shows a plot of $\mathrm{KD}$ as a function of Co thickness with $t_{\mathrm{Ni}}=8 \AA$. For this series, perpendicular magnetic anisotropy occurs for $t_{c_{0}}<5 \AA$. Curve fitting gives $\mathrm{K}_{\mathrm{v}}{ }^{\mathrm{Co}}=-9.2 \times 10^{6} \mathrm{erg} / \mathrm{cm}^{3}$ and $\mathrm{K}\left(\mathrm{t}_{\mathrm{Ni}}\right)=0.44 \mathrm{erg} / \mathrm{cm}^{2}$.

Fig. 2 shows the dependence of $\mathrm{KD}$ on $\mathrm{Ni}$ thickness for $t_{C o}=2 \AA$. Perpendicular magnetic anisotropy occurs over a wide range of $t_{\mathrm{Ni}}$, and $\mathrm{KD}$ decreases in an approximately linear manner:

$$
\begin{array}{r}
\mathrm{KD}=\mathrm{K}_{\mathrm{v}}{ }^{\mathrm{Ni}} \mathrm{t}_{\mathrm{Ni}}+\mathrm{K}\left(\mathrm{t}_{\mathrm{Co}}\right), \\
\text { with } \quad \mathrm{K}\left(\mathrm{t}_{\mathrm{C}_{0}}\right)=\mathrm{K}_{\mathrm{v}}{ }^{\mathrm{Co}} \mathrm{t}_{\mathrm{C}_{0}}+2 \mathrm{~K}_{\mathrm{i}} .
\end{array}
$$

We get $\mathrm{K}_{\mathrm{v}}{ }^{\mathrm{Ni}}=-9.6 \times 10^{5} \mathrm{erg} / \mathrm{cm}^{3}$ $\mathrm{K}\left(\mathrm{t}_{\mathrm{Co}_{0}}\right)=0.22 \mathrm{erg} / \mathrm{cm}^{2}$ from fitting the data to a line.

Substituting $\mathrm{K}_{\mathrm{v}}{ }^{\mathrm{Ni}}$ and $\mathrm{K}\left(\mathrm{t}_{\mathrm{Ni}}\right)$ data into Eq.(3) (or $\mathrm{K}_{\mathrm{v}}{ }^{\mathrm{Co}}$ and $\mathrm{K}\left(\mathrm{t}_{\mathrm{C}_{0}}\right)$ into $\mathrm{Eq}$ (5) ), we obtain $\mathrm{K}_{\mathrm{i}}=0.23 \pm 0.03 \mathrm{erg} / \mathrm{cm}^{2}$ without using any bulk $\mathrm{Co}$ and $\mathrm{Ni}$ anisotropy data. Positive $\mathrm{K}_{\mathrm{i}}$ confirms that the perpendicular magnetic anisotropy of $\mathrm{Co} / \mathrm{Ni}$ multilayer thin films at small $\mathrm{Co}$ and $\mathrm{Ni}$ layer thicknesses is due to the interface anisotropy. The $\mathrm{K}_{v}{ }^{\mathrm{Co}}$ and $\mathrm{K}_{v}{ }^{\mathrm{Ni}}$ values are comparable to published results ${ }^{[6],[7]}$. The $K_{i}$ value is smaller than that for

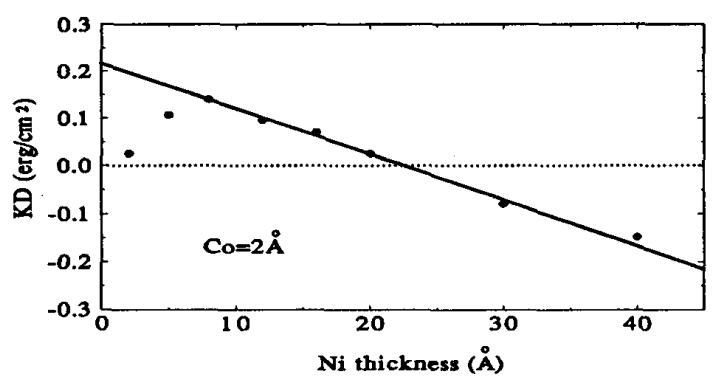

Fig. 2 Anisotropy constant times bilayer period as a function of $\mathrm{Ni}$ thickness for $8 \times(2 \AA \mathrm{Co} / t \AA \mathrm{Ni})$ the e-beam evaporated samples ${ }^{[4]}$, possibly because the samples made by e-beam evaporation have sharper interface boundaries.

The anisotropy constant, $K$, varied with sputtering conditions. With higher sputtering rate, $\mathrm{K}$ tends to increase. ${ }^{[6]}$ This will lead to a larger anisotropy constant.

\section{B. Effect of Buffer Layers}

To obtain perpendicular magnetic anisotropy, a selected metallic underlayer was necessary, ${ }^{[6]}$ since direct deposition on glass substrates gave strong in-plane anisotropy. We chose $\mathrm{Au}$ as the buffer layer. With variation of buffer layer thickness, the anisotropy constant changed dramatically as shown in the following table.

Variation of anisotropy constant $\mathrm{K}$ with Au buffer layers thickness for $8 \times(2 \AA \mathrm{Co} / 8 \AA \mathrm{Ni})$ multilayers

\begin{tabular}{ccc}
\hline \hline Samples No. & Au buffer layer thickness $(\AA)$ & $\mathrm{K}\left(\times 10^{4} \mathrm{erg} / \mathrm{cm}^{3}\right)$ \\
& & \\
& & \\
$\mathrm{Au}-1$ & 50 & -37 \\
$\mathrm{Au}-2$ & 150 & -3 \\
$\mathrm{Au}-3$ & 250 & 50 \\
$\mathrm{Au}-4$ & 350 & 60 \\
$\mathrm{Au}-5$ & 450 & 78 \\
$\mathrm{Au}-6$ & 550 & 100 \\
$\mathrm{Au}-7$ & 650 & \\
\end{tabular}

The $50 \AA$ and $150 \AA$ Au buffer layers could not provide sufficient (111) texture, so the films had in-plane anisotropy, similar to $\mathrm{Co} / \mathrm{Ni}$ multilayers on $\mathrm{Ag}$ buffer layers. ${ }^{[5]} \mathrm{Co} / \mathrm{Ni}$ multilayers on thick or annealed $\mathrm{Au}$ buffer layers ${ }^{[6]}$ had perpendicular magnetic anisotropy, due to the buffer layer's better (111) texture.. X-ray measurements support this argument.

$\mathrm{X}$-ray diffraction from $\mathrm{Co} / \mathrm{Ni}$ multilayer samples showed $\mathrm{Au}$ (111) and $\mathrm{Co} / \mathrm{Ni}$ (111) peaks. The Intensity of these peaks increased with increasing Au buffer layer thickness.

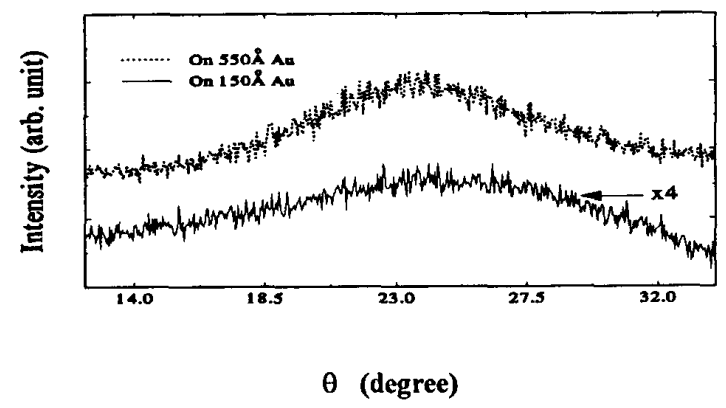

Fig. 3 Rocking curve measurement of $\mathrm{Co} / \mathrm{Ni}$ multilayers 
Fig.3 shows the rocking curve near the Co/Ni (111) peak. The peak intensity of the $\mathrm{Co} / \mathrm{Ni}$ on the $550 \AA$ film is much stronger, and the half width is smaller (less than $80 \%$ ) than on the Au $150 \AA$ film. This result is used to explain the increase in anisotropy constant, $K$, with increasing buffer layer thickness. Thicker Au buffer layers provide stronger $<111>$ direction perpendicular to the film plane in the $\mathrm{Co} / \mathrm{Ni}$ multilayer, which increases the perpendicular anisotropy ,K.

\section{Magneto-optical Properties}

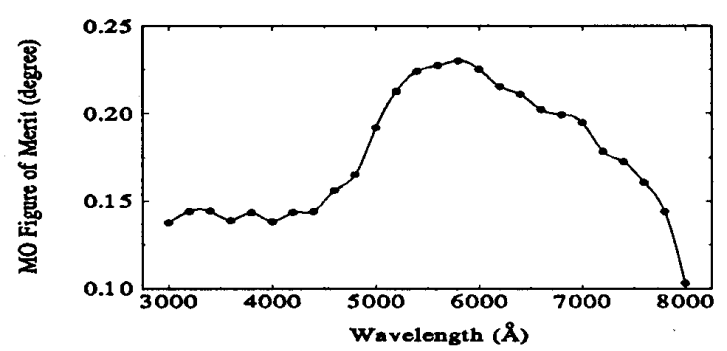

Fig. 4 Magneto-optical figure of merit

Fig. 4 shows the magneto-optical figure of merit $\left(\sqrt{\left(\theta_{\mathrm{k}}^{2}+\varepsilon_{\mathrm{k}}^{2}\right) R}\right.$ ) at room temperature. The figure of merit is larger than 0.1 degree over the entire spectral region and the peak is as high as 0.22 degree at about $5500 \AA$. Note that the MO figure of merit for $\mathrm{Co} / \mathrm{Ni}$ multilayers on $\mathrm{Au}$ buffer layers is larger than that of rare earth-transition metal alloys ${ }^{[8]}$ at short wavelengths. The magneto-optical figure of merit from Co/Ni samples is larger than for both $\mathrm{Co} / \mathrm{Pt}$ and Co/Pd for wavelengths $\lambda=5000 \sim 6000 \AA$, and is smaller than for $\mathrm{Co} / \mathrm{Pt}$ but larger than $\mathrm{Co} / \mathrm{Pd}$ for $\lambda=3000 \sim 4000$ $\AA^{[9],[10]}$

The temperature dependence of Kerr rotation and coercivity in our samples was investigated The sample studied was $8 \times(4 \AA \mathrm{Co} / 8 \AA \mathrm{Ni})$ and the temperature varied from $25^{\circ} \mathrm{C}$ to $350^{\circ} \mathrm{C}$. The results are given in Fig. 5 . This measurement was performed at $6328 \AA$. The Kerr rotation falls slowly as the temperature increases, and the

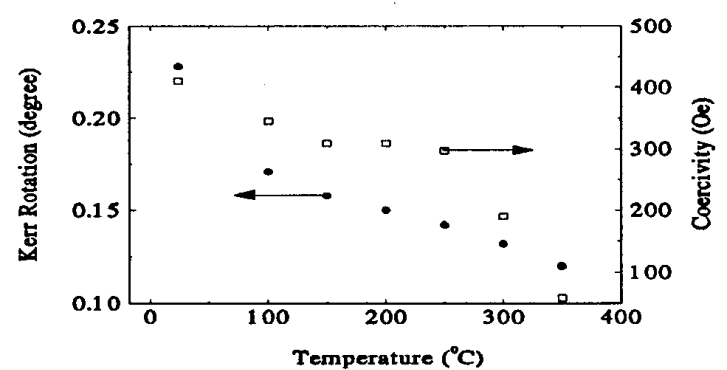

Fig. 5 Kerr rotation and coercivity as a function of temperature for $8 \times(4 \AA \mathrm{Co} / 8 \mathrm{~A} \mathrm{Ni})$ multilayer thin film. the coercivity dramatically drops at temperatures above $300^{\circ} \mathrm{C}$. These results are consistent with thermomagnetic writing measurements performed by den Broeder et al. ${ }^{[4]}$

\section{CONCLUSIONS}

Sputtered $\mathrm{Co} / \mathrm{Ni}$ multilayer thin films show perpendicular magnetic anisotropy when deposited on $\mathrm{Au}$ buffer layers. The perpendicular magnetic anisotropy arises from the interface anisotropy, where $\mathrm{K}_{\mathrm{i}}=0.23 \pm 0.03 \mathrm{erg} / \mathrm{cm}^{2}$ for our sputtered samples. Thicker $\mathrm{Au}$ buffer layers have better (111) texture which improves the (111) texture of the $\mathrm{Co} / \mathrm{Ni}$ multilayers, and consequently increase the perpendicular magnetic anisotropy. The measured magneto-optical properties indicate the $\mathrm{Co} / \mathrm{Ni}$ multilayers on $\mathrm{Au}$ buffer layers are similar to those of other Co-based multilayers, but are not as large in the blue wavelength region as for $\mathrm{Co} / \mathrm{Pt}$ multilayers.

\section{REFERENCES}

[1]. P. F. Carcia, A D. Meinhaldt, and A. Suna, "Perpendicular magnetic anisotropy in Pd/Co thin film layered structures", Appl Phys. Lett., vol.47, pp. 178-180, 1985.

[2]. B. N. Engel, C. D. England, R. A. Vanleeuwen, M. H. Wiedmann, and C. M. Falco, "Interface Magnetic Anisotropy in Epitaxial Superlattice", Phys. Rev. Lett., vol.67, pp. 1910-1913, 1991.

[3]. G. H. O. Daalderop, P. J. Kelly, and F. J. A. den Broeder, "Prediction and Confirmation of Perpendicular Magnetic Anisotropy in $\mathrm{Co} / \mathrm{Ni}$ Multilayers", Phys. Rev. Lett., vol.68, pp. 682-685, 1992.

[4]. F. J. A. den Broeder, H. W. van Kesteren, W. Hoving, and W. B. Zeper, "Co/Ni multilayers with perpendicular magnetic anisotropy: Kerr effect and thermomagnetic writing", Appl. Phys. Lett., vol.61, pp. 1468-1470 1992.

[5]. Y. B. Zhang, P. He, J. X. Shen, R. D. Kirby, D. J. Sellmyer and J. A. Woollam, "Magnetic and magneto-optic properties of sputtered $\mathrm{Co} / \mathrm{Ni}$ multilayers" J. Appl. Phys., vol.75, pp. 6495-6497, 1994.

[6]. F. J. A. den Broeder, E. Janssen, W. Hoving and W. B. Zeper, "Perpendicular Magnetic Anisotropy and Coercivity of Co/Ni Multilayers", IEEE Trans. Magn., vol.28, pp. 2760-2764, 1992.

[7]. M. T. Johnson, F. J. A den Broeder, J. J. de Vries, N. W. E. Mcgee, R. Jungbult and J. aan de Stegge, "perpendicular anisotropy of epitaxial wedge-shaped Co/Ni sandwiches grown on single crystal Cu substrates", J. MMM, vol.121, pp. 494-497, 1993.

[8]. P. F. Carcia, W. B. Zeper, H. W. van Kesteren, B. A. J. Javobs and J. H. M. Spurit, " materials challenges for metal multilayers as a magneto optical recording medium" Proceedings of the Magneto-Optical Recording International Symposium, pp.151-157, 1991.

[9]. D. Weller, W. Reim and K. Sporl, "Spectroscopy of multilayers for magneto optic storage" J. MMM, vol. 93, pp.183-193, 1991.

[10] Frans J. A. M. Greidanus and W. B. Zeper, "Magneto-optical Storage Materials”, MRS Bulletin, April pp. 31-38, 1990. 